\title{
The implementation of diary writing activity to improve students 'writing skill in Recount text at SMAN 1 Natar
}

\author{
Silvia Rahayu Anggraini ${ }^{1}$, Cucu Sutarsyah ${ }^{2}$, Huzairin ${ }^{3}$ \\ Universitas Lampung, Jl. Prof. Dr. Sumantri Brojonegoro, Bandarlampung 1,2,3 \\ 1 \\ Correspondence: rahayusilvia73@gmail.com
}

\begin{abstract}
The aim of this study are to find out whether there is significant improvement in students writing skill and to investigate what language features produced by students after being taught by using diary writing. The sample of this research was X IPS-4 at SMAN 1 Natar. The writing test was administered as the instrument of this research. The data were analyzed by using repeated measure t-test in which the significance was determined by $\mathrm{p}<0,005$. The result showed that the students ' mean score in pretest 60.82 while in the posttest mean score was 74.12 in which t-value>t-table $(11.882>2.452)$ or sig $\mathrm{p}<0.05(0.000<0.05)$. Furthermore, specific time and passive voice are the new language features that produced by students. It can be concluded that diary writing activity is effective to improve students 'writing skill.
\end{abstract}

Keywords: Writing diary activity, Writing skill, Recount text

\section{INTRODUCTION}

According to Meyers (2005) Writing is a way to produce language you do naturally when you speak. Writing is speaking to other on paper - or on a computer screen. Writing is also an action - a process of discovering and organizing your ideas, putting them on a paper and reshaping and revising them. As a writer writes, he performs an action of producing, organizing and expressing ideas in a way that is comprehensible for the reader or the audience. Since writing needs procedure and organization, writing deals with mixture of idea, vocabulary, and grammar. Harmer (2004) states that making good writing is more complex than producing speaking.

Furthermore, Al-Jawi (2011) points out that people often communicate through writing. When students can write well in English, they are not only can improve their writing skill, but also they can improve other skills. Because of that writing should be develop intensively, especially for learning English as the second language. Since writing is considered as the most difficult and boring activity or skill that need to be learned, people should have many ways to develop their writing skill that interesting for them. In mastering writing, even in the highest level of education, the students still find many difficulties. When they are asking to write, they are thinking about how to get ideas, how to develop them into sentences, and how to make a good construction of those sentences. The lack of idea or limited knowledge on something new can fall the desire and even the enthusiasm to write.

Anderson and Anderson define a recount text as a piece of text that retells past events, usually in the order in which they happened. From this definition, it can be seen that a recount text consists of past events that are ordered chronologically. It further means that we cannot write the events randomly as there are orders to follow that will make the text understandable. Furthermore, recount text can also 
be defined as a text that is basically written to make a report about an experience of a series of related event

Based on the pre-research at SMAN 1 Natar, it was found that many students have difficulties in learning writing; firstly, the students did not know what should they wrote even if they had idea in their brain. They did not how to start write their experience or idea and they were lack of background knowledge of the topic. Secondly, the students did not know the structure of the sentence and they did not when they will use past tense, present tense, or future tense. The problems might come from students 'background knowledge and concept of tenses itself. Thirdly, they were lacking of vocabulary. The last, most of the students did not put mechanic properly.

Therefore, the students' scores of writing were relatively low. In the teaching learning activity, recount text in writing skill should be interesting for the students. In fact, the majority of students felt not enthusiastic with the lesson. To solve those problems, the teachers realized that they needed to use appropriate teaching media to improve their writing scores so that the students could increase their writing skill. In writing there are five aspects that the students should improve: content, organization, vocabulary, language use, and mechanic.

Maharani (2017) states that first semester students of education were asked to write by developing their thoughts, ideas, experiences and even anything happened in their daily life they found difficulties. Some of them were extremely unconfident and reluctant to write due to some reasons. The main reason was that they thought they had nothing to write and when they had already got the ideas of what to write about, the lacks of vocabulary, grammar, and sentence organization made their ideas could not be properly conveyed. Concerning those statements, a suitable technique is really needed to help the students in their writing so that they can improve their writing. There are some applicable techniques to improve students' writing skill. One of the techniques that can be used and appropriate in teaching recount text is diary writing activity.

Diary writing has a number of advantages. It has the virtue of making writing an everyday activity, and, hence, it avoids the pressure one might feel when they are compelled to write (White and Amdt, 1991). As we write more often, writing becomes more natural and we might overcome the anxiety that accompanies formal writing. According to Hamp and Heasley (2006), diary writing gives learners the opportunity to practice free writing about what they want and whenever they want to. Another advantage is that the writer might explore experience which they might be reluctant to discuss with others, assuming that it is insignificant. Third, according Castellanos (2008) writing a personal record can stimulate the memory when one decides to do other types of writing. Sometimes a writer might think that there is nothing to write a bout. Diary writing can often help writers to brainstorm and retrieve ideas which generate topics for further elaborate writing tasks. In this sense, as Spanventa (2000) puts it, diary writing "helps writers develop their creativity."

Based on the explanations above, the Diary writing activity can help the students to improve the students' writing skill in recount text. Therefore, the researcher was interested to use this technique which was aimed at finding out a significant difference before and after the 
implementation of diary writing activity and to and to investigate what language features produced by students after being taught by using diary writing.

\section{METHODS}

This research used quantitative approach by using one group pre-test post-test design. Quantitative method is a method deals with statistical analysis data in the form of scores and numbers (Creswell, 2012). The population for this research is the students at the first grade of SMAN 1 Natar. The sample of his research, the researcher chooses 36 students from X IPS-4 by using purposive sampling. The data are collected by using tests (pre-test and post-test). Then, the improvement of students' test results are analyzed by using Repeated Measured T-Test to find out whether any significant difference of students' writing skill after the implementation diary writing activity.

\section{RESULTS AND DISCUSSION}

After conducting the research, the researcher gathers the result of the pre-test and post-test as Follow:

\section{Result}

Table 1. The Students 'Mean Score in Pre-test and Posttest

\begin{tabular}{|cccccc|}
\hline & N & Minimum & Maximum & Mean & Std. Deviation \\
\hline pre-test & 28 & 45.00 & 71.50 & 60.82 & 5.93517 \\
post-test & 28 & 55.00 & 85.00 & 74.12 & 6.03788 \\
$\begin{array}{c}\text { Valid N } \\
\text { (listwise) }\end{array}$ & 28 & & & & \\
\hline
\end{tabular}

Based on the table 1, it could be seen that the minimum score in pretest was 45.00 and the minimum score in posttest was 55.00. The increase of the minimum score was 10 . The maximum score in pretest was 71.50 and the maximum score in the posttest was 85.00. The increase of the maximum was 13.05. The mean score of the pretest was 60.82 and the posttest was 74.12. The increase of the mean score was 13.03

Table 2. Result of Paired Sample T-test

\section{Paired Samples Test}

\begin{tabular}{|l|c|c|c|c|}
\hline & Paired Differences & $\mathrm{t}$ & $\mathrm{d}$ & Sig. \\
\hline
\end{tabular}




\begin{tabular}{|c|c|c|c|c|c|c|c|c|}
\hline & \multirow[b]{2}{*}{ Mean } & \multirow{2}{*}{$\begin{array}{l}\text { Std. } \\
\text { Deviat } \\
\text { ion }\end{array}$} & \multirow{2}{*}{$\begin{array}{l}\text { Std } \\
\text { Err } \\
\text { or } \\
\text { Me } \\
\text { an }\end{array}$} & \multicolumn{2}{|c|}{$\begin{array}{l}95 \% \text { Confidence } \\
\text { Interval of the } \\
\text { Difference }\end{array}$} & & \multirow[t]{2}{*}{$\mathrm{f}$} & \multirow[t]{2}{*}{$\begin{array}{c}(2- \\
\text { tailed) }\end{array}$} \\
\hline & & & & Lower & Upper & & & \\
\hline $\begin{array}{ll}\mathrm{Pa} & \text { pretest }- \\
\text { ir } & \text { posttest } \\
1 & \end{array}$ & $\begin{array}{r}13.3035 \\
7\end{array}$ & $\begin{array}{r}3.933 \\
10\end{array}$ & $\begin{array}{r}.74 \\
32 \\
9\end{array}$ & $\begin{array}{r}14.82 \\
867\end{array}$ & $\begin{array}{r}11.77 \\
848\end{array}$ & $\begin{array}{r}17.8 \\
98\end{array}$ & $\begin{array}{l}2 \\
7\end{array}$ & .000 \\
\hline
\end{tabular}

The table showed that the t-value is 17.898 with degree of freedom $\mathrm{df}$ is 27 . While, the data significant based on the t-table points out at 2052. Thus, it can be concluded that the t-table (17.898 $>2052$ ) with the significant level is $5 \%$ or 0.05 . As a result, the null hypothesis is rejected and the research hypothesis $\left(\mathrm{H}_{1}\right.$ : there is a significant difference on students 'writing outcomes after having diary writing) is accepted. The table also reveals the increase of the outcomes is 13.30.

In order to answer research question what language features produced by the students after being taught by using diary writing activity the researcher were analyzed the students writing test in pretest and posttest by comparing their writing to find out new language features that produced by the students after the implementation of diary writing. The following students writing would explain language features that produce by the students

Last week I went to my grandma's house with my family. We went there by riding two motorbikes....(Asshy Siva Marselia.)

A couple months ago I went to the beach with my big family. The location is located on the coast of re martadinata, that is 15 kilometers away from my home. (Aulia Maharani Putri).

family had a vacation to Merak Beach, in our trip we enjoyed the holiday by joking together an enjoyed the music. (Nushrah Hidayat).

The last holiday I went to Bandung city. I went to Bandung with my family. I met with my brother who lived in Bandung. I spend my vacation in Bandung approximately 2 weeks. (Risya Aulia).

It was Tuesday, when our family first time went to Yogyakarta meet bude in there (Denaya Yuliana Putri).

ore the corona pandemic I went with my family on vacation to Jakarta. (M. Al Fadly Febrian).

One Sunday morning I was with my family planned to visit my brother house. (M. Al fadly Febrian).

From the example of students writing can be explained that there was a new language features that students produce except language features in recount text (using noun or pronoun, using adjective, using simple past, using conjunction and connector, using temporal sequence and using focus on specific participant) itself. 
The underlined sentences were the new language features that produce by students that specific time, although in pretest some students have been used specific time. While in language features of recount text specific time not include as the language features. Therefore specific time is the new language features that students produce after being taught by diary writing.

When I was taking pictures, I was shocked by person selling the accessories who approached me to offer they were selling...(Yuni Tri Indriafandi).

That day was Sunday where I followed selection in the school and I was chosen to follow next selection in the sub district....... being a member of paskriba is a matter of pride for me because in paskriba I was taught to be a discipline and responsible person. (Nabila Sahwa Nazala).

An experience that will never be forgotten by me...(Sinta Damayanti.

The example of students writing above with the underlined sentences was the language features that students produce after the treatment. Passive voice is the new language features that found it in their writing. In pretest the researcher didn't find a passive vice but when the researcher corrected the posttest, the researcher found some of students used passive voice in their writing. Therefore passive voice is new language features that students produce after being taught by diary writing.

\section{Discussions}

Referring on the research question on the research, the researcher would like to find out whether there is significant improvement in students writing skill after using diary writing and what language features produced by students after being taught by having diary writing.

As the researcher observed in the first meeting or pretest, the researcher found some problems in students writing ability in five aspects of writing. In first aspects of writing that is content, the researcher found that the students didn't know what should they wrote even they had idea in their brain, they didn't know how to start write their experience and also they were lack of background knowledge of the topic. In the second aspects of writing that is organization, the researcher found that the students did not know the structure of the sentence, for example "I am old sixteen years" so it should be changed into "I am sixteen years old". Then, the third aspect is vocabulary. The students ' vocabulary was still low, when the researcher asked the students to write their experience, they stuck in first word because they did not know what the vocabulary that they would write to start their writing, even though they had idea what they would to write. In language use aspect, the researcher found that the students did not know what the concept of past tense, when they made a past sentence they used verb 1 while past tense use verb 2. For example, "I am very happy" should be changed "I was very happy". For the last aspects of writing is mechanic, the researcher found that students did not put capitalization properly.

The treatment was given to the students in three meetings after administering the pretest. The first hypothesis was answered that there was an improvement in students 'writing ability after the researcher conducted the treatment. It can be seen from mean score between pretest and posttest where the difference is 13.03 (from 60.82 to 74.12). The mean score of pretest is 60.82 , in order to find out the students writing skill before the treatment, the researcher administered the pretest before 
implementing a diary writing in learning writing. Meanwhile, the mean score for the posttest is 74.12. Then the result was analyzed by using Repeated Measures T-Test, it was also found that the tvalue was higher than the t-table and the significant level was achieved. Therefore, it was confirmed that there was a significant difference of students 'writing recount text after the students were taught by using diary writing.

In this study, the researcher also analyzed language features that produced by students after being taught by diary writing. After the researcher analyzed the posttest have been done by the students, the researcher found that there were two language features that produced by students, they are specific time and passive voice. In the posttest most of students started their task by using specific time (The last holiday, A couple months ago, etc). While for language features of passive voice there were only 3 students that produced this language features. So, in analyzed language features that produced by students the researcher only found two new language features.

On the whole, by writing using diary writing the students 'ability in writing recount text improves. It could be seen in the posttest of students was better than before. When the researcher applied diary writing the students feel enthusiastic because they were familiar with diary they could write and express their idea freely without limited of topic. Langan (2008) says that keeping a dairy is one of excellent ways to get practice in writing and it will help the students develop the habit of thinking on paper. Diary or journal can also make writing as a familiar part of the students ${ }^{\text {ee }}$ life. After doing the research, it can obviously be seen that dairy writing which was applied in writing class successfully improves the students 'writing ability. It could be seen in the improvement of the achievement in diary writing.

Referring in the explanation above, the students can encourage their writing and motivate in learning writing by using diary writing. They were freely to write what their want without particular topic, they could express and develop their idea. Besides that, diary writing gives opportunities for students to develop their writing as stated by Ngoh (as cited in Tuan, 2010) states the benefit of diary writing that it also provides students with good opportunities to improve their writing skills and good chances to record their thoughts and feelings. In addition, it can be inferred that diary writing can improve students 'writing.

\section{CONCLUSIONS AND SUGGESTIONS}

\section{Conclusions}

Based on the data analysis and discussion of the research findings, the researcher comes to the following conclusions. There was a significant difference of students 'writing ability after being taught by using diary writing which could be seen from the value of two railed significance which is lower than $0.05(0.000<0.05)$. It also supported by the students 'score of pre-test and posttest which improve from 60.82 to 74.12 . It can be concluded that diary writing activity is effective to improve students' writing skill in recount text. Diary writing help students produce new language features except recount text language features: Specific time, as had been explained in the previous chapter 
some of students produced this language features, they put specific for example the last holiday, a couple months ago, etc in first paragraph when they started write their experience. Passive voice, as had been explained in the previous chapter, in this language features there were only 3 students that produced passive voice. They put passive voice in the middle of the paragraph. The clarification presented above, indicates that the students produced two new language features.

\section{Suggestions}

Referring to the conclusion above, the researcher would like to recommend some suggestions as follows: Since there is a significant difference of students' writing ability after being taught by using diary writing activity. Since writing is a skill they will be better with the practice so English teachers should consider diary writing as one of the media in learning activity to provide students practice in writing both in the classroom and outside the classroom. The teachers should be more effective in ordering the material to avoid the students feel bored. The teachers need to pay attention in using past tense because the students sometime use verb 1 in writing in recount text. This research is just one effort to help students for improving their writing skill through diary writing. For other researcher who considers for conducting the similar research which is related to the use of diary writing with same or other text types, the result of this research can be one of the references. The researcher suggest to other future research to find out the number of existed language features or not in the students writing test. The researcher also suggests conducted this research for taking the treatments more than 3 times in order to make students understands the material more clearly.

\section{REFEENCES}

Al Jawi, F. (2011). Teaching the receptive skills: listening \& reading skills (Handbook). Mecca : UMM Al Qura University Press.

Anderson, Mark \& Kathy, A. (1997). Text types in English. South Yarra: MacMillan Education.

Castellanos, J. (2008). Journal writing and its benefits in an upper intermediate EFL class. Profile:

Issues in Teachers 'Professional Development, 9(1), 111-128.

Creswell, John, W. (2012). Educational research. Boston: Pearson Education, Inc.

Hamp-Lyons, L. \& Heasly, B. (2006). Study writing (2nd Edition). Cambridge: Cambridge University Press.

Harmer, J. (2004). How to teach writing. Essex: Longman Group. Ltd.

Langan, J. (2008). College writing skills with reading 7th Edition. New York: McGraw-Hill, Inc.

Maharani, M. M. (2017). Improving students' writing through Diary writing. World Class Islamic University.

Meyers, A. (2005). Gateways to academic writing: effective sentences, paragraphs and essays. New York: Pearson Education, Inc.

Tuan, L. (2010). Enhacing EFL learners: writing skills via journal writing. English Language Teaching Journal vol.3.

Spaventa, S. (2000). Essay writing. Cambridge: Cambridge University.

White. R. \& Arndt, V. (1991). Process writing. London: Longman. 